\title{
TEKNIK PENGUKURAN NITRAT-NITROGEN DENGAN METODE BRUCINE
}

\author{
Siti Mariyam*) \\ *Teknisi Litkayasa pada Loka Riset Pemacuan Stok Ikan, Jatiluhur \\ Teregristasi I tgl. 15/9/2005; Disetujui terbit tgl. 13/2/2007
}

\section{PENDAHULUAN}

Di perairan alam unsur nitrogen terdapat dalam bermacam-macam bentuk, tergantung pada tingkat oksidasi antara lain $\mathrm{NH}_{3}$ (amoniak), $\mathrm{NO}_{3}$ (nitrat), $\mathrm{NO}_{2}$ (Nitrit). Nitra adalah salah satu bentuk senyawa nitrogen yang teroksidasi dengan tingkat oksidasi +3 , merupakan senyawa yang memiliki sifat mudah larut dalam air dan stabil. Di perairan nitrat merupakan sumber utama sebagai nutrien bagi pertumbuhan tanaman dan alga (Effendi 2003). Sumber nitrat berasal dari buangan industri bahan peledak, pupuk, piroteknik, dan lain-lain. Kadar nitrat secara alami agak rendah, tetapi bisa tinggi pada air yang diberi pupuk mengandung nitrat. Kadar nitrat tidak boleh melebihi $10 \mathrm{mg} / \mathrm{l}$. Untuk menentukan kadar nitrat di perairan pada umumnya digunakan metode nessler.

Kini telah berkembang metode lain yaitu metode brucine (APHA 1978) dalam limnologi. Metode brucine sangat sesuai untuk sample air yang kadar nitratnitrogennya 0,1-2 ppm. Reaksi brucine dengan nitrat akan membentuk senyawa yang berwarna kuning. Kecepatan reaksi dipengaruhi oleh tingkat panas larutan. Pemanasan larutan dilakukan dengan penambahan pereaksi brucine dan asam sulfat pekat. Tulisan ini menjelaskan teknik pengukuran nitratnitrogen dengan metode brucine.

\section{POKOK BAHASAN}

Bahan dan alat yang digunakan

Bahan:

- Sampel air dari Waduk Ir. H. Djuanda

Kertas saring wathmen ukuran $42 \mathrm{~mm}$

Larutan brucine

Asam sulfat pekat

Silfanilic acid

- Larutan standar nitrat

Alat:

- Water sampel dengan volume 3 liter

- Botol sampel

- Corong dari plastik

- Erlenmeyer

- Tabung reaksi volume $15 \mathrm{ml}$

- Gelas ukur volume $10 \mathrm{ml}$

- Tabung spektronic

- Spektronic 20

Cara Kerja:

1. Saring sampel air sebanyak $25-50 \mathrm{ml}$ dengan menggunakan kertas saring whatman

2. Pipet $5 \mathrm{ml}$ sampel yang telah di saring, masukan kedalam gelas piala

3. Tambah $0,5 \mathrm{ml}$ brucine, aduk

4. Tambah $5 \mathrm{ml}$ asam sulfat pekat (gunakan ruang asam), aduk

5. Buat larutan blangko dari $5 \mathrm{ml}$ aguades. Tambahkan larutan $\mathrm{NO}_{3}$ dan $\mathrm{NO}_{4}$

6. Buat larutan standar nitrat-nitrogen dengan konsentrasi seperti pada Tabel 1.

Tabel $1 . \quad$ Konsentrasi larutan standar nitrat-nitrogen

\begin{tabular}{cc}
\hline $\begin{array}{c}\text { ppm Nitrat-N } \\
\text { yang ingin dibuat }\end{array}$ & $\begin{array}{c}\text { ml standar nitrat-N (5 ppm) yang diperlukan untuk } \\
\text { diencerkan menjadi 100 } \mathbf{~ m l}\end{array}$ \\
\hline 0,025 & 0,50 \\
0,05 & 1,00 \\
0,10 & 2,00 \\
0,25 & 5,00 \\
0,50 & 10,00 \\
0,75 & 15,00 \\
1,00 & 20,00 \\
\hline
\end{tabular}


Sebelum pengenceran sampai dengan $100 \mathrm{ml}$, tambahkan terlebih dahulu 20-30 ml aguades dan 8 $\mathrm{ml} \mathrm{NH}_{4} \mathrm{OH}$ pekat, kemudian ditambahkan lagi aguades sampai tanda tera, selanjutnya lakukan prosedur 2 , 3, dan 4.

Dengan larutan blanko dan pada panjang gelombang $410 \mathrm{~nm}$, set spektrofotometer pada 0,000 trasmisi, kemudian ukur sampel dan larutan standar.
- Buat persamaan regresi $(\mathrm{Y}=\mathrm{A}+\mathrm{BX})$ dari larutan standar untuk menentukan kadar nitrat-nitrogen.

Untuk menentukan kadar nitrat, dalam nitrat per liter (= ppm $\mathrm{NO}_{3}^{-}$), digunakan persamaan berikut.

Hasil pengukuran nitrat-nitrogen dengan metode brucine di Waduk Ir. H. Djuanda dapat dilihat pada tabel 2.

$$
\mathrm{Mg} \mathrm{NO}_{3}-/ /=\mathrm{ppm} \mathrm{NO}_{3}-\mathrm{N} \times \frac{\mathrm{BM} \mathrm{NO}_{3}}{\mathrm{BAN}}=\mathrm{ppm} \mathrm{NO}_{3} \times 4,4
$$

Tabel 2. Hasil pengukuran kandungan Nitrat-N (mg/l ) dari Waduk Ir. H. Djuanda

\begin{tabular}{lcc}
\hline Stasiun & Kedalaman $(\mathbf{m})$ & Kandungan Nitrat-N $\mathbf{( m g} / \mathbf{l})$ \\
\hline Parung Kalong & 0 & 1,560 \\
& 2 & 2,145 \\
& 4 & 1,531 \\
Keramba & Dasar & 2,291 \\
& 0 & 0,302 \\
& 2 & 0,755 \\
& 4 & 0,463 \\
Cilalawi & 8 & 1,472 \\
& Dasar & 0,492 \\
& 0 & 0,390 \\
& 2 & 0,156 \\
\end{tabular}

\section{KESIMPULAN}

Kandungan nitrat di Waduk Ir. H. Djuanda selama penelitian berkisar antara 0,004-0,141 mg/l dengan menggunakan metode nessler, sedangkan dengan metode brucine berkisar antara 0,156-2,291 mg/l metode brucine sangat efektip dan metode ini sesuai untuk air sampel yang kadar nitratnya 0,1 sampai 2 ppm.

\section{DAFTAR PUSTAKA}

APHA (American Public Health Association) 1978. Standrad Methods for the Examination of Water and Wastewater.

Effendi, H. 2003. Telaah kualitas air bagi pengelolaan sumber daya dan lingkungan perairan. Fakultas Perikanan-Institut Pertanian Bogor. 